\title{
Peran Media Time Lines Chart dalam Pembelajaran IPS di Sekolah Dasar
}

\section{Dwilusiyana Nurulanjani}

Mahasiswa Program Studi PGSD Universitas Pendidikan Indonesia Kampus Sumedang J. Mayor Abdurachman No. 211 Sumedang

Email: dwilusiyana@student.upi.edu

\begin{tabular}{|c|c|}
\hline ABSTRACT & ABSTRAK \\
\hline $\begin{array}{l}\text { Media plays an important role in the learning } \\
\text { process. Many research results reveal the media } \\
\text { give effect to the improvement of student } \\
\text { learning outcomes. Initial findings of the research } \\
\text { in Grade } V \text { SDN Sindangjati, Paseh-Sumedang } \\
\text { showed that students have low historical thinking } \\
\text { skills because the subject of history study in IPS } \\
\text { subjects contains abstract facts, which are } \\
\text { difficult to understand what made the students } \\
\text { difficult to remember when and what happens in } \\
\text { historical events as part of historical thinking skill. } \\
\text { Efforts were made to overcome these problems } \\
\text { by using the media timelines chart. The result of } \\
\text { research using Classroom Action Research } \\
\text { Method shows that the media timelines chart } \\
\text { can increase the historical thinking skill. The } \\
\text { improvement can be seen from the increasing } \\
\text { percentage of historical thinking skill in cycle I } \\
\text { which was } 62.50 \% \text { then, becoming } 87.50 \% \text { in } \\
\text { cycle II. It means that the media timelines chart } \\
\text { in learning IPS material of Proclamation historical } \\
\text { events can increase historical thinking skills. This } \\
\text { means that the historical thinking test of social } \\
\text { studies learning historical material of the } \\
\text { Proclamation event has fulfilled the targeted } \\
\text { objective of } 84.38 \% \text {. }\end{array}$ & $\begin{array}{l}\text { Media Pembelajaran memegang peranan yang } \\
\text { penting dalam pembelajaran, banyak hasil } \\
\text { penelitian mengungkapkan media memberikan } \\
\text { pengaruh terhadap peningkatan hasil belajar } \\
\text { siswa. Temuan awal penelitian di kelas V SDN } \\
\text { Sindangjati, Paseh-Sumedang memperlihatkan } \\
\text { siswa memiliki kemampuan historical thinking skill } \\
\text { yang rendah, dikarenakan materi kajian sejarah } \\
\text { dalam mata pelajaran yang padat IPS banyak } \\
\text { memuat fakta-fakta yang abstrak sehingga sulit } \\
\text { untuk dipahami yang berdampak pada siswa } \\
\text { cenderung sulit untuk mengingat kapan dan } \\
\text { apa saja yang terjadi dalam peristiwa sejarah } \\
\text { yang merupakan keterampilan berpikir sejarah } \\
\text { (historical thinking skill). Upaya yang dilakukan } \\
\text { untuk mengatasi masalah tersebut dengan } \\
\text { menggunakan media time lines chart. Hasil } \\
\text { penelitian dengan menggunakan Metode } \\
\text { Penelitian tindakan kelas (PTK) memperlihatkan } \\
\text { media time lines chart dapat meningkatkan } \\
\text { historical thinking skill siswa. Peningkatan tersebut } \\
\text { diketahui dari peningkatan persentase historical } \\
\text { thinking skill pada siklus I yaitu 62,50\%, siklus II } \\
\text { sebesar 87,50\%. Artinya media time lines chart } \\
\text { pada pembelajaran IPS materi sejarah peristiwa } \\
\text { Proklamasi memiliki peran dalam meningkatkan } \\
\text { historical thinking skill. }\end{array}$ \\
\hline $\begin{array}{l}\text { Keywords: media time lines chart, historical } \\
\text { thinking skill. }\end{array}$ & $\begin{array}{l}\text { dia time lines chart, histo } \\
\text { litian tindakan kelas. }\end{array}$ \\
\hline
\end{tabular}

How to Cite: Nurulanjani, D. (2018). Peran Media Time Lines Chart Dalam Pembelajaran IPS di Sekolah Dasar. Mimbar Sekolah Dasar, 5(1), 43-50. doi:http://dx.doi.org/10.17509/mimbar-sd.v5i1.9302.

PENDAHULUAN Pendidikan memegang peranan penting dalam membentuk karakter anak bangsa menuju masyarakat yang cerdas, untuk ikut andil bersama membangun dan mewujudkan cita-cita luhur bangsa. "Mencerdaskan kehidupan bangsa" ini merupakan visi pendidikan yang tercantum dalam Pembukaan
Undang-Undang Dasar (UUD) tahun 1945 (Dananjaya, 2010, p. 6). Menjadi "Masyarakat cerdas" merupakan kesempatan semua warga negara tanpa terpilah-pilah oleh batasan tertentu, karena pendidikan diperuntukkan bagi seluruh warga negara seperti yang diamanatkan dalam pasal 31 UUD 1945, 
Dwilusiyana Nurulanjani, Peran Media Time Lines Chart dalam Pembelajaran IPS...

bahwa "Semua warga negara berhak memperoleh pendidikan". Tergantung pada bagaimana kita mau memanfaatkan kesempatan itu untuk mengoptimalkan diri memperoleh pendidikan.

Mengingat bahwa siswa belajar merupakan konsekuensi dari guru yang mengajar, maka gurulah yang harus mendapat perhatian supaya meningkat kualitasnya, dan akhirnya akan bermuara pada keberhasilan siswa. Belajar, merupakan suatu proses yang akan menghasilkan perubahan, menyangkut pengetahuan, keterampilan, sikap, dan nilai-nilai (Uno, 2007; Hamalik, 2005). Seperti juga yang dituliskan oleh Winkel (1991, p. 200) bahwa "proses pembelajaran adalah suatu aktivitas psikis atau mental yang berlangsung dalam interaksi aktif dalam lingkungan, yang menghasilkan perubahan-perubahan pengetahuan, pemahaman, keterampilan dan nilai sikap"

IPS sebagai ilmu pengetahuan yang memadukan sejumlah konsep pilihan dari cabang-cabang ilmu sosial dan ilmu lainnya yang kemudian diolah berdasarkan prinsip-prinsip pendidikan disampaikan kepada peserta didik dengan harapan peserta didik akan mendapatkan perubahan pengetahuan, pemahaman, keterampilan sekaligus nilai sikap yang terwujud dalam konteks good citizenship (Jarolimeck, 1993). Sebagai pelajaran yang dihasilkan dari memfusikan atau paduan dari sejumlah mata pelajaran sosial, IPS merupakan bagian dari kurikulum sekolah yang berhubungan dengan manusia di dalam masyarakat Nasution (Hanifah, dkk 2009, p. 121).

Upaya pengenalan sejarah bangsa melalui penyelenggaraan pendidikan membawa visi yang sangat penting bagi pembinaan karakter anak bangsa. Melalui sejarah pula, manusia belajar dari pengalaman sejarah untuk menyikapi masalah yang mungkin muncul dikemudikan hari. Hal ini sejalan dengan apa yang diungkap Sumaatmaja (1986) bahwa "...dengan mengetahui sejarah masa lampau kita dapat memperhitungkan kejadian masa yang akan datang". Pengenalan sejarah bangsa melalui pendidikan direalisasikan dengan menjadikan materi sejarah sebagai salah satu kajian mata pelajaran yang dikemas secara terpadu ke dalam mata pelajaran IImu Pengetahuan Sosial (IPS).

Seperti materi ilmu sosial lainnya, Sejarah yang merupakan bagian dari mata pelajaran IPS mempunyai peran yang penting karena di dalam sejarah mengandung nilai kepahlawanan yang patut untuk diteladani. Selain itu, mempelajari sejarah bermanfaat bagi siswa dalam menghadapi permasalahan yang akan dihadapi sebagai penerus bangsa, selain itu siswa akan memiliki rasa nasionalisme dan rasa tanggungjawab untuk mempertahankan kemerdekaan dan sebagai tolak ukur untuk memajukan Negara Indonesia sebagai Negara yang maju. Terlihat jelas bahwa pengenalan 
sejarah melalui pendidikan dimaksudkan agar para peserta didik sebagai calon generasi penerus bangsa mampu menyikapi masalah kehidupannya di kemudian hari.

Anak didik tidak hanya akan mengetahui peristiwa-peristiwa kehidupan masa lampau, namun mereka dihantarkan pada kemampuan mengambil pesan dari sejarah itu sendiri yang kelak di masa depan akan menjadi perhitungan dalam menghadapi permasalahan hidupnya. Selain itu mempelajari sejarah akan membawa dampak positif bagi anak didik dalam kehidupan, yaitu dengan terbinanya aspirasi mereka tentang sebuah kesenian dan kebudayaan hidup yang sedang mereka alami. Sebagaimana yang dituturkan oleh Sumaatmadja (1986, p.14), "Melalui materi dan pengungkapan sejarah, kita akan dapat memupuk aspirasi anak didik tentang kesenian, kebudayaan, dan kehidupan pada umumnya".

Fenomena yang muncul yaitu sebagian besar siswa mengalami kesulitan dalam pembelajaran IPS yang di dalamnya terdapat materi sejarah. Siswa menganggap materi sejarah sulit untuk dipahami, diingat, dan membosankan. Hasil penelitian yang dilakukan oleh Hasnawati (2012), mencatat jika sebagian besar materinya bersifat deskriptif yang kronologis jika hanya disampaikan melalvi ceramah akan sulit diterima oleh siswa dan membosankan. Hasil studi awal mengenai pembelajaran IPS pada materi sejarah di kelas $\mathrm{V}$ SDN Sindangjati menguraikan bahwa fokus permasalahan ada pada kesulitan siswa dalam merunutkan tanggal dan tahun kejadian peristiwa mengingat kapan dan apa saja yang terjadi dalam peristiwa sejarah yang merupakan keterampilan berpikir sejarah (historical thinking skill), karena materi yang banyak sehingga sulit untuk dikonkritkan.

Teori perkembangan kognitif Piaget, mencatatkan hasil penelitian anak usia Sekolah Dasar pada rentang usia 7-11 tahun tergolong ke dalam tahapan perkembangan kognitif operasional konkret (Santrock, 2007). Artinya, belum dapat berpikir sesuatu yang abstrak karena jalan berpikirnya masih terbatas pada situasi yang konkret.

Alternatif yang dapat dilakukan untuk mengatasi permasalahan tersebut, antara lain dengan menggunakan media pembelajaran. Hasil kajian Oktavianti (2014, p. 66) melaporkan faktor yang juga berpengaruh terhadap keberhasilan pembelajaran adalah media pembelajaran yang di gunakan oleh guru dalam proses pembelajarannya, karena media pembelajaran merupakan perantara atau pengantar terjadinya komunikasi yang baik dan menyenangkan antara guru dengan siswanya. Semangat belajar siswa akan muncul ketika suasana begitu menyenangkan dan belajar akan efektif bila seseorang dalam keadaan gembira dalam belajar 
Dwilusiyana Nurulanjani, Peran Media Time Lines Chart dalam Pembelajaran IPS...

Beberapa hasil studi mengenai peran media pembelajaran dikaji oleh Suciati dan Untari (2016), Reffiane dan Mazidati (2016), dan Sunaengsih (2016). Media menjadi penting adanya, karena penggunaan media pembelajaran yang tepat dapat membantu proses penyampaian informasi atau pesan dalam pembelajaran sehingga dapat berlangsung secara efektif.

Penggunaan media pembelajaran pada materi sejarah peristiwa Proklamasi harapannya dapat meningkatkan historical thinking skill siswa. Historical thinking skill atau dapat disebut juga keterampilan berpikir sejarah merupakan langkah awal untuk belajar sejarah. Dengan berpikir sejarah maka siswa dapat memahami materi mengenai sejarah karena dalam historical thinking skill siswa dituntut untuk berpikir kronologis sehingga dapat membedakan peristiwa apa dan kapan terjadinya sesuai urutan waktu.

Historical thinking skills merupakan kemampuan berpikir kesejarahan yang memungkinkan anak/siswa untuk membedakan masa lalu, masa sekarang, dan masa yang akan datang; membangun pertanyaan; mencari dan mengevaluasi bukti-bukti; membandingkan dan menganalisis kisah - kisah sejarah, ilustrasi-ilustrasi, dan catatan-catatan dari masa lalu; menginterpretasikan catatancatatan sejarah; dan mengkonstruksinarsi sejarah menurut versi masing-masing siswa atau anak (Kamarga, 2000). Jadi, dapat dikatakan historical thinking skill merupakan kemampuan berpikir sejarah yang dapat membedakan suatu kejadian dan peristiwa yang disertai dengan membangun pertanyaan, mencari bukti dan membandingkan kisah-kisah sejarah dari waktu ke waktu.

Salah satu cara untuk meningkatkan kemampuan historical thinking skill membangun pertanyaan mengenai materi sejarah. Indikator historical thinking skill siswa yang akan dijadikan pengukuran dalam penelitian ini yaitu indikator chronological thinking (berpikir kronologis) dan historical research capabilities yaitu membuat pertanyaan-pertanyaan mengenai materi peristiwa proklamasi. Dengan demikian siswa diharapkan mampu terampil dalam berpikir sejarah untuk dapat memahami materi mengenai sejarah peristiwa Proklamasi.

Media yang digunakan yaitu media pembelajaran time lines chart. Media time lines chart diartikan dalam bahasa Indonesia berarti bagan garis waktu. Mityasari \& Suprayitno (2013, p.3) mengemukakan,

Media time lines chart merupakan media berupa susunan garis-garis yang menekankan kepada suatu perkembangan atau proses berdasarkan urutan waktu terjadinya dan berfungsi menyalurkan pesan kepada penerima yang bertujuan untuk merangsang pikiran, perhatian, perasaan, dan minat sehingga terjadi proses belajar yang menarik dan berkesan bagi siswa. 
Media time lines chart merupakan media yang dirancang sesuai dengan urutan waktu secara berurutan dan kronologis dengan menjelaskan materinya berbentuk bagan (chart). Media time lines chart ini cocok digunakan untuk menyampaikan materi pembelajaran yang menghubungkan antara suatu peristiwa dengan waktu, yaitu bagan garis waktu (time line chart). Dapat disimpulkan bahwa media time lines chart merupakan media yang dirancang sesuai dengan urutan waktu secara berurutan dan kronologis dengan menjelaskan materinya berbentuk bagan (chart). Dengan menggunakan media time lines chart sehingga siswa mampu memahami materi ajar yang guru sampaikan.

\section{METODE}

Penelitian yang dilakukan yaitu penelitian tindakan kelas (PTK). Penelitian ini bertujuan untuk memperbaiki permasalahan yang ada di kelas ke arah hasil yang lebih optimal. Penelitian ini dilakukan karena ditemukannya permasalahan dalam pembelajaran. Menurut Arikunto, dkk (2015, p. 194), "PTK merupakan suatu penelitian yang akar permasalahannya muncul di kelas, dan dirasakan langsung oleh guru yang bersangkutan sehingga sulit dibenarkan jika ada anggapan bahwa permasalahan dalam PTK diperoleh dari persepsi/renungan seorang peneliti". Jelaslah bahwa penelitian tindakan kelas (PTK) merupakan suatu upaya memperbaiki proses pembelajaran dimulai dari ditemukannya permasalahan di kelas yang kemudian diperbaiki agar mencapai hasil yang lebih optimal. Desain penelitian yang dipilih oleh peneliti adalah dengan menggunakan model spiral dari Kemmis dan Mc. Taggart. Hanifah (2014, p.53) mengemukakan bahwa:

Model yang dikemukakan oleh
Kemmis \& Mc. Taggart pada
hakekatnya berupa perangkat-
perangkat atau untaian-untaian
dengan satu perangkat terdiri dari
empat komponen, yaitu:
perencanaan, tindakan,
pengamatan, dan refleksi. Keempat
komponen yang berupa untaian
tersebut dipandang sebagai satu
siklus. Oleh karena itu, pengertian
siklus pada kesempatan ini adalah
suatu putaran kegiatan yang terdiri
dari perencanaan, tindakan,
pengamatan, dan refleksi.

\section{HASIL DAN PEMBAHASAN}

Dalam penelitian ini terdapat data awal yang didapatkan pada materi sejarah peristiwa Proklamasi. Adapun Kriteria Ketuntasan Minimal (KKM) sebesar 64. Siswa kelas $\vee$ SDN Sindangjati berjumlah 32 siswa, dari 32 siswa hanya sebesar $37,5 \%$ yang dinyatakan tuntas yaitu sebanyak 12 siswa, sedangkan 20 siswa tidak tuntas yaitu sebesar $62,5 \%$. Dengan hasil data tersebut maka dapat disimpulkan bahwa pembelajaran IPS mengenai materi sejarah peristiwa Proklamasi belum optimal.

Oleh karena itu, langkah awal untuk mengatasi permasalahan pada materi tersebut memanfaatkan media pembelajaran. Media yang dimaksud yaitu media time lines chart. Media ini digunakan untuk meningkatkan keterampilan berpikir sejarah (historical thinking skill) siswa. 
Dwilusiyana Nurulanjani, Peran Media Time Lines Chart dalam Pembelajaran IPS...

Dengan historical thinking skill, siswa dapat mengingat materi peristiwa sejarah, sehingga dapat membedakan peristiwa apa dan kapan terjadinya sesuai urutan waktu. Untuk menentukan hasil penelitian ditentukan taarget pencapaian historical thinking skill siswa yaitu $84,38 \%$.

Penelitian tindakan yang dilakukan dengan menggunakan media time lines chart pada materi sejarah peristiwa Proklamasi dilakukan selama dua siklus. Dari siklus tersebut memuat hasil peningkatan historical thinking skill siswa pada materi sejarah peristiwa Proklamasi. Adapun perbandingan data awal dengan hasil siklus I dan siklus || historical thinking skill siswa pada materi peristiwa Proklamasi terlihat pada diagram 1 di bawah ini.

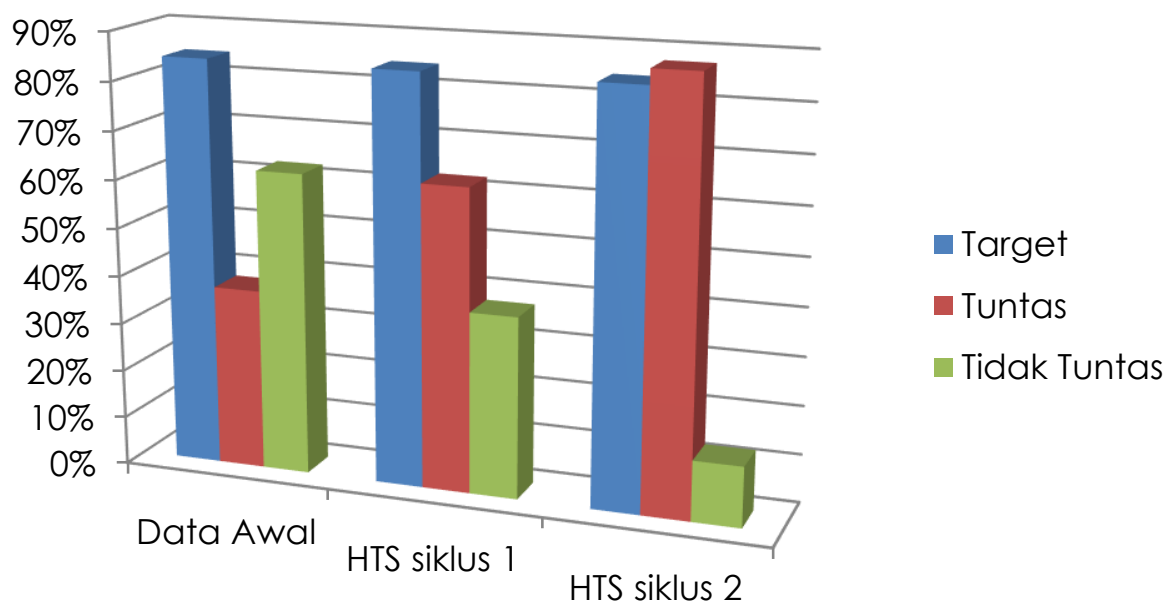

Diagram 1. Peningkatan Hasil Historical Thinking Skill Siswa Kelas V SDN Sindangjati

Berdasarkan diagram 1, pada siklus I terdapat 20 siswa yang tuntas memenuhi nilai KKM yaitu sebesar $62,50 \%$ dan 12 siswa yang tidak tuntas memenuhi nilai KKM yaitu sebesar 37,50\%. Pada siklus I ini hasil historical thingking skill siswa yang di dapat belum mencapai target yang ditentukan, maka dilaksanakan perbaikan dan pelaksanaan pembelajaran berdasarkan hasil analisis dan refleksi pada siklus berikutnya yaitu siklus II. Pada siklus ke II terdapat peningkatan hasil historical thinking skill siswa pada materi sejarah peristiwa Proklamasi. Pada siklus ke II hasil historical thingking skill siswa meningkat sebesar $87,50 \%$ sebanyak 27 siswa, sedangkan yang tidak tuntas 4 siswa $(12,50 \%)$. Siklus ke II meningkat dan mencapai target pencapaian karena adanya refleksi yang dilakukan pada siklus sebelumnya. Pada siklus ke II dalam penjelasan cara menggunakan media lebih dipahami oleh siswa dibandingkan dengan siklus sebelumnya, dan siswa sudah dapat membuat pertanyaan dengan benar mengenai materi peristiwa Proklamasi yang merupakan salahsatu indikator pencapaian historical thinking skill, sehingga pada siklus II historical thingking skill siswa mencapai target pencapaian yang ditentukan. 
Hasil penelitian mempertegas peran media sebagai alat yang dapat menyampaikan pesan-pesan pembelajaran, untuk mendorang siswa belajar secara cepat, tepat, mudah, benar dan tidak terjadinya verbalisme. Bahkan, membantu siswa di dalam memahami dan memperoleh informasi yang dapat didengar ataupun dilihat oleh panca indera sehingga pembelajaran dapat berhasil dan berdaya guna (Arsyad, 2007); Hanafiah \& Suhana, 2010); Prihatin, 2008).

\section{SIMPULAN}

Berdasarkan hasil dari pembelajaran yang dilakukan dua siklus, pembelajaran IPS pada materi sejarah peristiwa Proklamasi terjadi peningkatan historical thinking skill siswa kelas $V$ SDN Sindangjati dengan menggunakan media pembelajaran time lines chart. Media time lines chart memudahkan siswa untuk mengahafal dan mengingat materi peristiwa sejarah Proklamasi yang berdampak pada meningkatnya historical thinking skill siswa.

\section{REFERENSI}

Arikunto. (2015). Penelitian tindakan kelas. Jakarta: Bumi Aksara.

Arsyad. (2007). Media Pembelajaran. Jakarta: PT. Raja Grafindo Persada.

Hamalik. O.( 2005). Proses Belajar Mengajar. Jakarta: Bumi Aksara.

Hanafiah \& Suhana. (2010). Konsep Strategi Pembelajaran. Bandung: PT Refika Aditama.

Hanifah, N. (2014). Memahami Penelitian Tindakan Kelas: Teori dan Aplikasinya. Bandung: UPI PRESS.

Hanifah, N., dkk. (2009). Model Pembelajaran Di Sekolah Dasar. Bandung: UPI Press.

Hasnawati, N. (2012). Perbedaan Hasil Belajar IPS Sejarah Antara Siswa Yang
Diajar dengan Menggunakan Metode Karyawisata dan Metode Konvensional Di Kelas VII Mts Sunan Kalijogo Malang. SKRIPSI. Malang: Universitas Negeri Malang Fakultas IImu Sosial Jurusan Sejarah Program Studi S1 Pendidikan Sejarah.

Jarolimek, John and Walter C. Parker. (1993). Social Studies in Elementary Education. New York: Macmillan Publishing Company.

Kamarga, H. (2000). Advance Organizers: Sebuah Model Pembelajaran dalam Mengembangkan Aspek Berpikir Kesejarahan di Sekolah Dasar. Historia Jurnal Pendidikan Sejarah. I (2).

Mityasari, D.Y. dan Suprayitno. (2013). Judul: Penggunaan Bagan Garis Waktu (Time Line Chart). Jurnal PGSD FIP Universitas Negeri Surabaya. 1 (2).

Oktavianti, R., \& Wiyanto, A. (2014). PENGEMBANGAN MEDIA GAYANGHETUM (GAMBAR WAYANG HEWAN DAN TUMBUHAN) DALAM PEMBELAJARAN TEMATIK TERINTEGRASI KELAS IV SD. Mimbar Sekolah Dasar, 1 (1), 65-70.

doi:http://dx.doi.org/10.17509/mimbarsd.vli1.865

Prihatin, Eka. (2008). Guru Sebagai Fasilitator. Bandung: Karsa Mandiri Persada.

Reffiane, F., \& Mazidati, I. (2016). IMPLEMENTASI PENGEMBANGAN MEDIA WAYANG KERTON PADA TEMA KEGIATAN SEHARI-HARI. Mimbar Sekolah Dasar, 3(2), 163-170.

Santrock. J. W. (2007). Perkembangan Anak. Jilid 1 Edisi kesebelas. Jakarta: PT. Erlangga.

Suciati, S., Septiana, I., \& Untari, M. (2016). EFEKTIVITAS MEDIA MONOPOLI BERBAHASA (MONOSA) DALAM PEMBELAJARAN TEMATIK INTEGRATIF DI SD KELAS IV. Mimbar Sekolah Dasar, 3(2), 136-150. doi:http://dx.doi.org/10.23819/mimbarsd.v3i2.4253.

Sumaatmadja, N. (1986). Pengantar Studi Sosial. Bandung: PT. Alumni.

Sunaengsih, C. (2016). PENGARUH MEDIA PEMBELAJARAN TERHADAP MUTU PEMBELAJARAN PADA SEKOLAH DASAR TERAKREDITASI A. Mimbar Sekolah Dasar, $3(2)$, 183-190. doi:http://dx.doi.org/10.23819/mimbarsd.v3i2.4259. 
Dwilusiyana Nurulanjani, Peran Media Time Lines Chart dalam Pembelajaran IPS...

Uno, Hamzah B. (2007). Model Pembelajaran Menciptakan Proses Belajar Mengajar yang Kreatif dan Efektif. Jakarta: Bumi Aksara.

Winkel. (1991). Psikologi Pengajaran. Jakarta: Gramedia. 